\title{
KAJIAN KAPASITAS LENTUR BALOK BETON BERTULANGAN BAMBU PETUNG
}

\author{
(Flexural Capacity Assessment of Bamboo Petung Reinforce Concrete Beams)
}

\author{
Reni Nuraeni $^{1}{ }^{*}$, Meiske Widyarti $^{1}$, Asep Sapei ${ }^{1}$ \\ ${ }^{1}$ Departemen Teknik Sipil dan Lingkungan, Fakultas Teknologi Pertanian, Institut Pertanian Bogor. \\ Jl. Raya Dramaga, Kampus IPB Dramaga, PO BOX 220, Bogor, Jawa Barat Indonesia \\ *Penulis korespondensi: mizrie3112@gmail.com
}

Diterima: 29 Desember 2017

Disetujui: 4 Agustus 2018

\begin{abstract}
Reinforced concrete construction generally uses reinforcement from steel material. Reinforcing steel is a mining product whose existence will eventually run out. Considering the price of steel reinforcement today is relatively high, it is necessary to find substitution materials that are more affordable but have relatively the same structural strength. Therefore the replacement of steel reinforcing material with reinforcement from bamboo material can be felt as a solution to overcome this problem. The reason for choosing bamboo material is the availability of material that is quite a lot, easily obtained and the price is relatively cheap. In this study will examine the flexural capacity of bamboo petung reinforcing beams with a notch $2 \mathrm{~cm}$ and $3 \mathrm{~cm}$ apart. The cross section of the bamboo reinforcement is in the form of a circle (1/4) circle and (1/2) a circle of bamboo cross section. The results of this study aim to obtain cross-sectional shape and distance of notches with flexural capacity values that approximate the flexural capacity of steel reinforced concrete beams. The results of the initial test obtained the value of bamboo tensile strength (ftr) an average of $288.81 \mathrm{MPa}$ with the highest tensile strength value of 333.43 $M P a$. Concrete design mix is made with the quality of $f^{\prime} c=17.5$ MPa referring to SNI 7394-2008. The average compressive strength $\left(f^{\prime} \mathrm{c}\right)$ of concrete samples at 3 days is 9,837 Mpa so that it can be predicted at 28 days of concrete life will reach strong press 24,592 MPa. beam samples made 9 types of reinforcement. As a result of beam bending testing at 28 days, the type TB4 beam produced a flexural strength value of 10,176 MPa approaching the value of the steel beam's bending strength of 12,000 MPa.
\end{abstract}

Keywords : bamboo petung, flexural beams, reinforcement bamboo

\section{PENDAHULUAN}

Salah satu material struktur yang umum digunakan adalah beton bertulang. Konstruksi beton bertulang umumnya menggunakan tulangan dari material baja. Baja tulangan adalah produk hasil tambang yang keberadaannya suatu saat akan habis (Pathurahman dan Kusuma 2003). Mengingat harga tulangan baja dewasa ini relatif tinggi sehingga perlu di cari material subtitusi yang lebih terjangkau namun memiliki kekuatan struktur yang relatif sama. Oleh karena itu penggantian material tulangan baja dengan tulangan dari material bambu dirasakan dapat menjadi solusi untuk mengatasi masalah tersebut. Alasan pemilihan material bambu adalah ketersediaan material yang cukup banyak, mudah diperoleh dan harga relatif murah (Budi 2010). Oleh karena itu, pemenuhan kebutuhan struktur bangunan yang lebih terjangkau dapat dipenuhi.

Penggantian tulangan baja dengan material bambu telah banyak dilakukan dalam penelitian ilmiah. Berdasarkan penelitian Handayani et al. (2014), kolom bertulangan baja dengan diameter rata-rata $7.7 \mathrm{~mm}$ dan luas permukaan tulangan baja $93.08 \mathrm{~mm}^{2}$, diperoleh tegangan lelehnya sebesar 460.827 Mpa sedangkan bambu Petung polos dengan luas penampang 
rata-rata $105.84 \mathrm{~mm}^{2}$ didapatkan tegangan leleh sebesar 299.67 MPa. Modulus elastisitas tarik ( $\mathrm{E}$ tarik) rata-rata dari sampel pengujian tulangan baja adalah $277812 \mathrm{MPa}$. Modulus elastisitas tarik (E tarik) rata-rata dari sampel pengujian bambu petung adalah 37513.69 MPa(Handayani et al. 2014).

Bentuk bambu yang berupa tabung dengan sekat-sekat yang disebut buku mempunyai sifat mekanis. Terdapat banyak macam bambu, tetapi dari ratusan jenis itu, hanya ada empat macam saja yang dianggap penting sebagai jenis bambu dan yang umum dipasarkan di Indonesia (Frick 2004), yaitu bambu Petung (Sunaryo et al. 2015), bambu Wulung (Triyana et al.2014), bambu Tali (Bachtiar et al. 2008b) dan bambu Ori (Handayani et al. 2007).

Mix design beton dibuat mengacu pada SNI 7394-2008. Kualitas beton di cek melalui pengujian kuat tekan sampel silinder beton yang dilakukan mengacu pada SNI 1974-2011. Peningkatan kuat tekan beton sesuai dengan umur beton mengacu pada PBI 1971.

Dalam penelitian ini akan mengkaji kapasitas lentur dari balok bertulangan bambu petung dengan takikan berjarak 2 $\mathrm{cm}$ dan $3 \mathrm{~cm}$. Bentuk penampang dari tulangan bambu berupa lengkung $\frac{1}{4}$ lingkaran dan $\frac{1}{2}$ lingkaran penampang bambu. Hasil dari penelitian ini bertujuan untuk memperoleh bentuk penampang dan jarak takikan dengan nilai kapasitas lentur yang mendekati nilai kapasitas lentur balok beton bertulangan baja.

\section{METODOLOGI}

Metodologi penelitian yang digunakan dalam penelitian ini adalah metode eksperimental laboratorium. Penelitian ini dilakukan di Laboratorium Kekuatan Bahan dan Laboratorium Struktur Departemen Teknik Sipil dan Lingkungan, Fateta IPB. Pengambilan data dan pengujian dilaksanakan mulai dari 3 Juni 2017 sampai dengan 8 Juli 2017.

Bahan yang digunakan dalam penelitian ini adalah angregat kasar, agregat halus,_semen portland, tulangan baja P. $8 \mathrm{~mm}$, tulangan sengkang baja P.6 $\mathrm{mm}$, kawat beton, rencana mix design 17.5 $\mathrm{MPa}$ dan jenis bambu Petung yang diperoleh dari pedagang bambu wilayah Citeureup Kabupaten Bogor. Alat yang akan dipergunakan antara lain United Testing Machine manual merk Simadzu UMH-30, United Testing Machine Otomatis WAW-2000 Series, Concrete Mixer, slump test set, timbangan digital dan manual, cetakan beton, tongkat besi dan tong air.

Tahapan penelitian yang dilaksanakan dapat dilihat melalui ilustrasi pada Gambar 1.

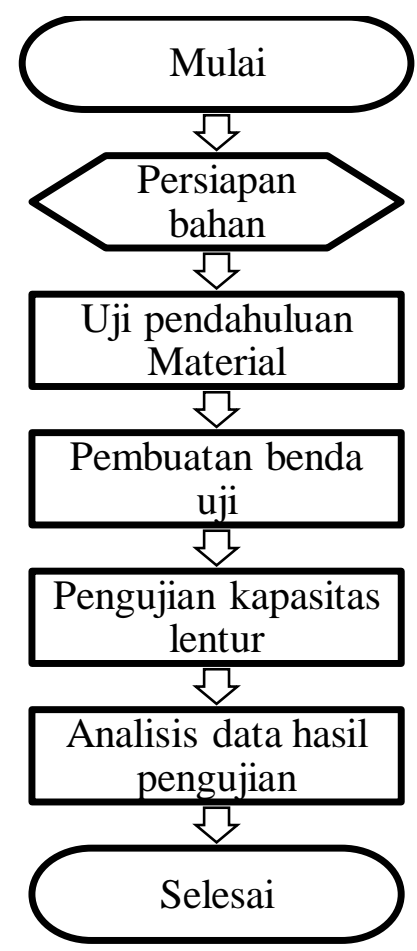

Gambar 1 Diagram Alir Penelitian

Persiapan bahan-bahan antara lain : bambu petung, agregat kasar berukuran 2-3 cm, agresar halus menggunakan pasir Cimangkok, semen kemasan $50 \mathrm{~kg}$, kawat beton, tulangan baja P.8 $\mathrm{mm}$ untuk 
tulangan utama dan P.6 mm untuk sengkang. Bambu diperoleh dari pedagang bambu di sekitar wilayah Citeureup Kabupaten Bogor. Bambu dipilih berdasarkan ukuran diameter, sedangkan untuk umur bambu dipilih dengan umur 23 tahun berdasarkan rekomendasi penjual. Tidak dilakukan perlakuan khusus pada bambu yang telah dipilih, hanya disimpan di tempat yang terlindung dari panas dan hujan. Bambu dibuat sebanyak 8 variasi bentuk tulangan (Gambar 2), tulangan bambu kemudian dirangkai menggunakan tulangan baja begel P. $6 \mathrm{~mm}$ dengan skema penulangan dapat dilihat pada Gambar 3 dan Gambar 4.

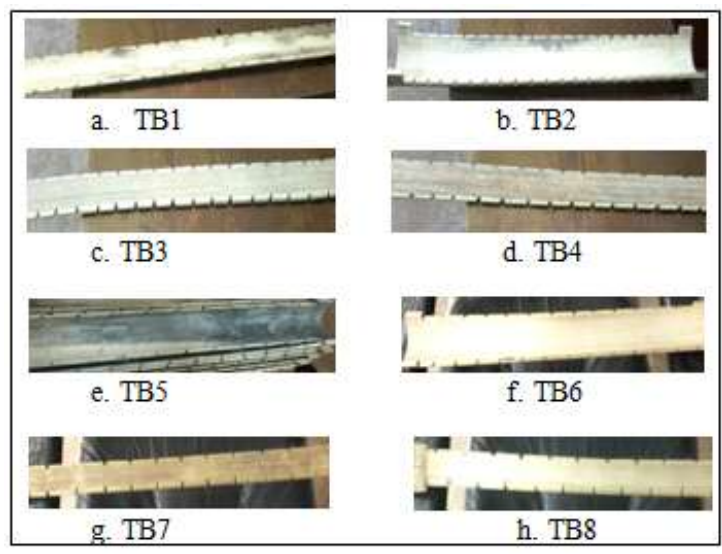

Gambar 2 Variasi Tulangan Bambu

Agregat kasar berupa batu pecah dipilih yang berukuran berkisar 2-3 $\mathrm{cm}$. Agregat kasar diperoleh dari toko material sekitar daerah Ciampea, tidak ada perlakuan khusus terhadap agregat kasar hanya dimasukan kedalam karung kemudian disimpan di tempat yang lindung dari panas dan hujan selama \pm 1 minggu tanpa diayak. Seperti halnya agregat kasar, agregat halus yang dipergunakan dalam penelitian adalah pasir Cimangkok yang diperoleh dari toko material sekitar wilayah Ciampea. Tidak ada perlakuan khusus pada pasir, hanya dimasukan kedalam karung dan disimpan di tempat yang terlindung dari panas maupun hujan tanpa diayak. Kondisi pasir saat digunakan dalam penelitian dalam keadaan kering udara, tidak dilakukan pengukuran kadar air pada pasir. Untuk semen digunakan jenis PCC (portland composite cement) kemasan $50 \mathrm{~kg}$ yang diperoleh dari toko material sekitar wilayah Ciampea. Baja P.8 mm digunakan sebagai tulangan utama. Baja P.8 dipotong sepanjang $60 \mathrm{~cm}$, pada setiap ujungnya dibengkokkan sepanjang 2,5 $\mathrm{cm}$ kemudian dirangkai membentuk tulangan dengan pengikat menggunakan baja begel P.6 mm (Gambar 5).

Pengujian tarik sampel bambu (Gambar 6) mengacu pada SNI 03-33991994 tentang metode pengujian kuat tarik kayu di laboratorium dan pengujian tekan campuran beton. Sampel bambu untuk uji tarik dibuat sebanyak 5 buah dengan panjang $41 \mathrm{~cm}$ dan lebar $2 \mathrm{~cm}$, sepanjang $15 \mathrm{~cm}$ pada bagian tengah dibuat menipis sampai dengan $\pm 2-3 \mathrm{~mm}$ pada tengah batang uji. Pengujian tarik bambu menggunakan alat Universal Testing Machine (UTM) manual di Laboratorium

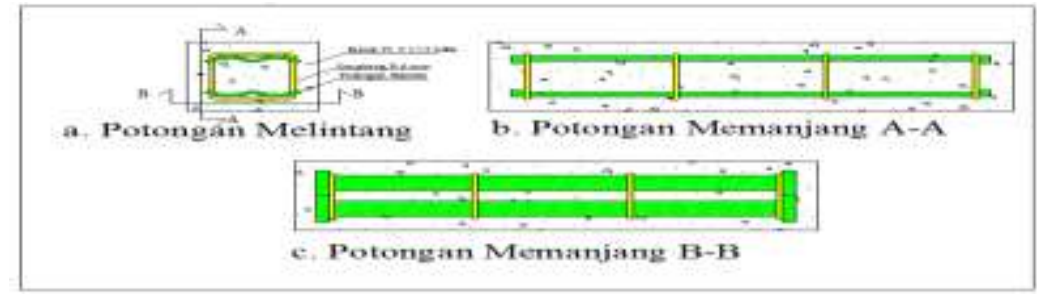

Gambar 3 Skema Penulangan Bambu 1/4 Lingkaran 


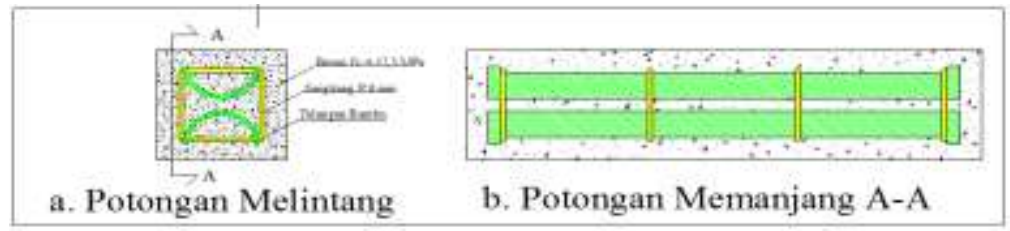

Gambar 4 Skema Penulangan Bambu 1/2 Lingkaran

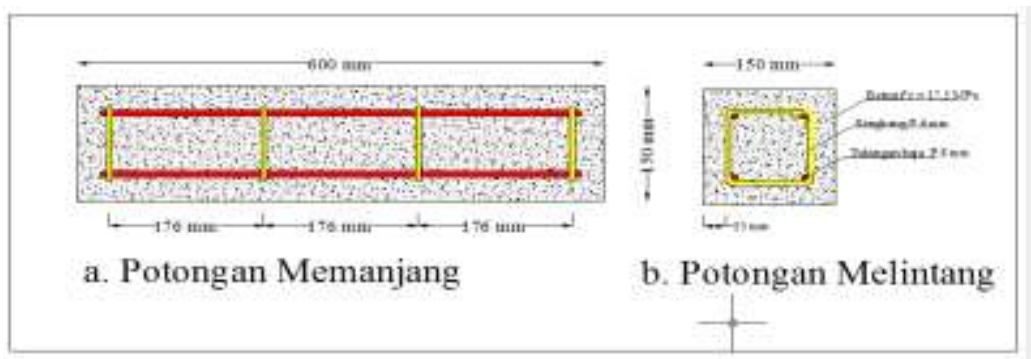

Gambar 5 Skema Penulangan Baja P.8 mm

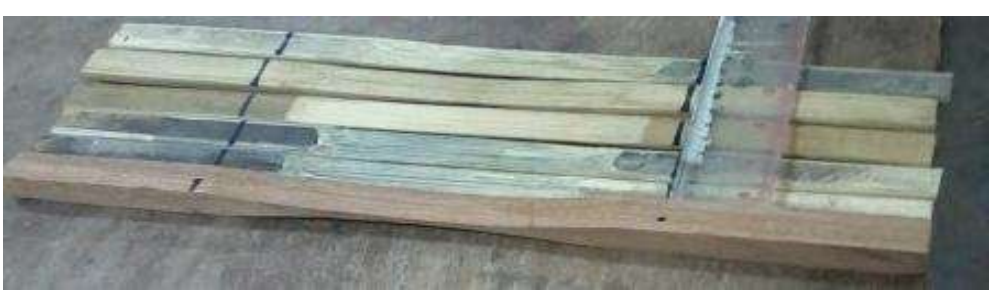

Gambar 6 Sampel Uji Tarik Bambu

Kekuatan Bahan Departemen Teknik Sipil dan Lingkungan Fateta IPB. Perhitungan kuat tarik menggunakan persamaan 1 :

$$
f_{t r}=\frac{P}{b \cdot h}(M P a)
$$

Dimana:

$f_{t r}=$ kuat tarik dalam satuan megapascal (MPa).

$P=$ beban maksimum yang mengakibatkan keruntuhan balok uji dalam satuan Newton.

$b$ = lebar bambu rata-rata penampang runtuh dalam satuan milimeter ( $\mathrm{mm}$ ).

$h$ = tebal bambu rata-rata pada penampang sampel dalam satuan milimeter $(\mathrm{mm})$.

Untuk pengujian campuran beton di buat dengan cetakan silinder(Gambar 7) diameter $10 \mathrm{~cm}$ dan tinggi $15 \mathrm{~cm}$ dengan jumlah 3 buah. Pengujian tekan silinder beton mengacu pada SNI 1974-2011 menggunakan alat Universal Testing Machine (UTM) otomatis di Laboratorium Struktur Departemen Teknik Sipil dan Lingkungan Fateta IPB. Pengujian tekan dilakukan pada saat umur sampel 3,kemudian prediksi kuat tekan pada umur 28 berdasarkan PBI 1971 (tabel 3). Kuat tekan dihitung dengan persamaan 2 :

$$
f_{t k}=\frac{P}{A}\left(\mathrm{~kg} / \mathrm{cm}^{2}\right)
$$

\section{Dimana :}

$f_{t k}=$ kuat tekan dalam satuan kilogram per sentimeter persegi $\left(\mathrm{kg} / \mathrm{cm}^{2}\right)$.

$P=$ beban maksimum yang mengakibatkan keruntuhan balok uji dalam satuan kilogram $(\mathrm{kg})$.

$A=$ luas penampang sampel dalam satuan sentimeter persegi $\left(\mathrm{cm}^{2}\right)$. 


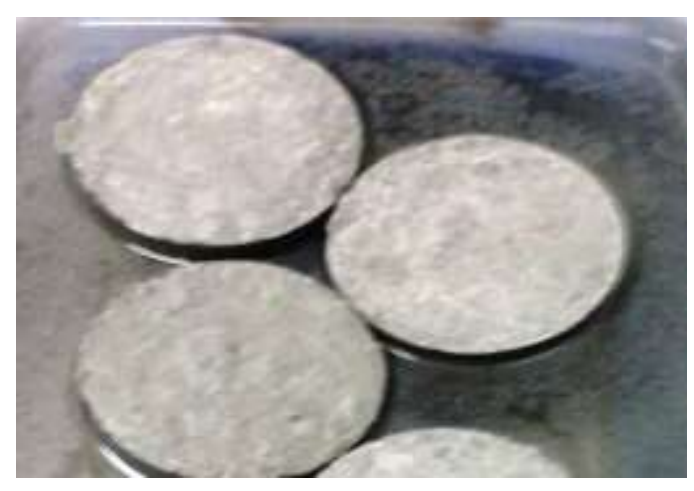

Gambar 7 Sampel Silinder Beton

Pembuatan benda uji dibuat 9 tipe dengan dimensi $150 \mathrm{~mm} \times 150 \mathrm{~mm} \times 600$ $\mathrm{mm}$ sebanyak 3 buah setiap tipenya (Tabel
1). Mix design beton dibuat dengan mutu $f^{\prime} c=17.5 \mathrm{MPa}$ mengacu pada SNI 73942008. Berdasarkan SNI 7394-2008 untuk menghasilkan $1 \mathrm{~m}^{3}$ beton dengan kuat tekan 17,5 $\mathrm{MPa}$ dan slump $12 \pm 2 \mathrm{~cm}$ (Gambar 8), komposisi bahannya adalah sebagai berikut : $357 \mathrm{~kg}$ PC,723 kg pasir beton, $1035 \mathrm{~kg}$ splite dan 215 liter air. Benda uji balok dibuat sesuai SNI 24932011 tentang tata cara pembuatan dan perawatan benda uji beton dilaboratorium. Proses pencampuran menggunakan alat concrete mixer. Variasi tulangan bambu dibuat sebanyak 8 tipe.

Tabel 1 Variasi benda Uji Balok

\begin{tabular}{rllclrl}
\hline No & Tulangan & Jarak Takikan & Penampang & keterangan & Jumlah & Kode \\
\hline 1 & Baja P.8 & & $\mathrm{O}$ & - & 3 & TP \\
2 & Bambu & $2 \mathrm{~cm}$ & $1 / 2 \mathrm{O}$ & Sejajar & 3 & TB1 \\
3 & Bambu & $2 \mathrm{~cm}$ & $1 / 2 \mathrm{O}$ & Tak sejajar & 3 & TB2 \\
4 & Bambu & $2 \mathrm{~cm}$ & $1 / 4 \mathrm{O}$ & Sejajar & 3 & TB3 \\
5 & Bambu & $2 \mathrm{~cm}$ & $1 / 4 \mathrm{O}$ & Tak sejajar & 3 & TB4 \\
6 & Bambu & $3 \mathrm{~cm}$ & $1 / 2 \mathrm{O}$ & Sejajar & 3 & TB5 \\
7 & Bambu & $3 \mathrm{~cm}$ & $1 / 2 \mathrm{O}$ & Tak sejajar & 3 & TB6 \\
8 & Bambu & $3 \mathrm{~cm}$ & $1 / 4 \mathrm{O}$ & Sejajar & 3 & TB7 \\
9 & Bambu & $3 \mathrm{~cm}$ & $1 / 4 \mathrm{O}$ & Tak sejajar & 3 & TB8 \\
\hline
\end{tabular}

Sebelum tahapan pengujian, proses curing pada sampel balok beton bertulang dilakukan selama 28 hari dengan cara direndam dalam air/ditutup dengan karung basah. Pengujian kuat lentur balok dilakukan pada variasi umur 7 hari, 14 atau 21 hari dan 28 hari menggunakan UTM (Universal Testing Machine) otomatis di Laboratoriun Sruktur Departemen Teknik Sipil dan Lingkungan Fateta IPB.

Data hasil pengujian kemudian di analisis untuk memperoleh nilai kuat lentur dari sampel balok yang di uji. Nilai kuat lentur balok beton di hitung

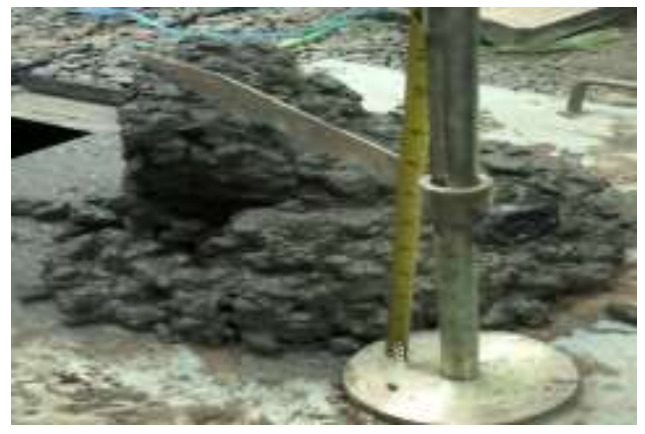

Gambar 8 Uji Slump Campuran Beton

berdasarkan Persamaan 3 sesuai SNI 034154-1996.

$$
f_{l t}=\frac{3 P L}{2 b d^{2}}
$$


Dimana :

$f_{l t}=$ kuat lentur dalam satuan megapascal(MPa).

$P=$ beban maksimum yang mengakibatkan keruntuhan balok uji dalam satuan (Newton).

$L=$ panjang bentang diantara kedua blok tumpuan dalam satuan milimeter (mm).

$b=$ lebar balok rata-rata penampang runtuh dalam satuan milimeter (mm).

$d=$ tinggi balok rata-rata pada pemanpang runtuh dalam satuan milimeter (mm).

\section{HASIL DAN PEMBAHASAN}

Hasil pengujian tekan sampel silinder beton dapat dilihat pada Tabel 2 dan hasil pengujian tarik bambu dapat dilihat pada Tabel 3. Hasil dari pengujian awal diperoleh nilai kuat tarik $\left(f_{b}\right)$ bambu rata-rata sebesar 288,81 MPa dengan nilai kuat tarik tertinggi sebesar 333, $43 \mathrm{MPa}$. Nilai kuat tarik dari sampel bambu yang di uji mendekati nilai kuat tarik baja BjTP 24 sebesar $380 \mathrm{MPa}$ (SNI 2002). Besar kuat tekan rata-rata $\left(f^{\prime} c\right)$ sampel beton pada umur 3 hari sebesar 9,837 Mpa sehingga dapat diprediksikan pada umur beton 28 hari akan mencapai kuat tekan sebesar 24,592 MPa.

Hasil dari pengujian lentur sampel balok (gambar 9) disajikan per variasi tulangan dalam bentuk grafik (gambar 10). Untuk lebih memperjelas hasil dari pengujian lentur sampel balok beton bertulang, maka akan di uraikan hasil setiap tipe dari sampel balok beton bertulang yang di uji.

Tabel 2 Pengujian Tekan Beton pada Umur 3 Hari

\begin{tabular}{lllll}
\hline Sampel & berat $(\mathrm{gr})$ & $\mathrm{A}\left(\mathrm{mm}^{2}\right)$ & $\mathrm{P}(\mathrm{N})$ & $\mathrm{f}_{\mathrm{tk}}(\mathrm{MPa})$ \\
\hline 1 & 3353 & 7850 & 86668.4 & 11.04056051 \\
2 & 3318 & 7850 & 68334.7 & 8.705057325 \\
3 & 3500 & 7850 & 76668.2 & 9.7666496882 \\
\hline
\end{tabular}

Tabel 3 Pengujian Tarik Bambu

\begin{tabular}{rrrrrrrrr}
\hline $\begin{array}{l}\text { No } \\
\text { Sampel }\end{array}$ & $\begin{array}{l}\mathrm{P} \\
(\mathrm{kgf})\end{array}$ & $\mathrm{L}(\mathrm{mm})$ & $\begin{array}{l}\mathrm{L} \\
(\mathrm{mm})\end{array}$ & $\begin{array}{l}\mathrm{b} \\
(\mathrm{mm})\end{array}$ & $\begin{array}{l}\mathrm{h} \\
(\mathrm{mm})\end{array}$ & $\begin{array}{l}\mathrm{f}_{\mathrm{tr}} \\
\left(\mathrm{kgf} / \mathrm{mm}^{2}\right)\end{array}$ & $\mathrm{f}_{\mathrm{tr}}(\mathrm{MPa})$ & $\varepsilon$ \\
\hline 1 & 960 & 150 & 10 & 20 & 2 & 24.00 & 235.44 & 0.0667 \\
2 & 1340 & 150 & 16 & 20 & 2 & 33.50 & 328.64 & 0.1067 \\
3 & 1360 & 150 & 16 & 20 & 2 & 34.00 & 333.54 & 0.1067 \\
4 & 1040 & 150 & 16 & 20 & 2 & 26.00 & 255.06 & 0.1067 \\
5 & 1190 & 150 & 15 & 20 & 2 & 29.75 & 291.85 & 0.1000 \\
\hline
\end{tabular}

\section{Balok Tipe TP}

Hasil pengujian nilai kuat lentur $\left(f_{l t}\right)$ sampel balok beton bertulangan baja (TP) pada umur 7,14 dan 28 hari adalah 10.074 $\mathrm{MPa}, 11.500 \mathrm{MPa}$ dan 12.000 $\mathrm{MPa}$. Dari hasil pengujian lentur sampel balok tipe TP nilai kuat lentur balok semakin meningkat seiring dengan pertambahan umur sampel balok. Nilai dari pengujian sampel balok tipe TP ini akan dijadikan sebagai pembanding untuk nilai dari sampel balok tipe yang lainnya.(Gambar 10) 


\section{Balok Tipe TB1}

Hasil pengujian nilai kuat lentur $\left(f_{l t}\right)$ sampel balok beton bertulangan bambu (TB1) pada umur 7,14 dan 28 hari adalah 7.556 MPa, 8.833 MPa dan 9.000 MPa. Dari hasil pengujian lentur sampel balok tipe TB1 nilai kuat lentur balok semakin meningkat seiring dengan pertambahan umur sampel. Akan tetapi bila dibandingkan dengan nilai dari sampel tipe TP hasilnya masih jauh lebih kecil. Besar selisih pada umur sampel balok pada umur 28 hari adalah sebesar $3 \mathrm{MPa}$. (Gambar 10)

\section{Balok Tipe TB2}

Hasil pengujian nilai kuat lentur $\left(f_{l t}\right)$ sampel balok beton bertulangan bambu (TB1) pada umur 7,14 dan 28 hari adalah 6,222 $\mathrm{MPa}, 8,167 \mathrm{MPa}$ dan 8,833 $\mathrm{MPa}$. Dari hasil pengujian lentur sampel balok tipe TB2 nilai kuat lentur balok semakin meningkat seiring dengan pertambahan umur sampel. Akan tetapi bila dibandingkan dengan nilai dari sampel tipe TP hasilnya masih jauh lebih kecil. Besar selisih pada umur sampel balok pada umur 28 hari adalah sebesar 3,167 MPa. (Gambar 10)

\section{Balok Tipe TB3}

Hasil pengujian nilai kuat lentur $\left(f_{l t}\right)$ sampel balok beton bertulangan bambu (TB1) pada umur 7,14 dan 28 hari adalah 6,024 MPa , 8,667 MPa dan 9,000 MPa. Dari hasil pengujian lentur sampel balok tipe TB3 nilai kuat lentur balok semakin meningkat seiring dengan pertambahan umur sampel. Akan tetapi bila dibandingkan dengan nilai dari sampel tipe TP hasilnya masih jauh lebih kecil. Besar selisih pada umur sampel balok pada umur 28 hari adalah sebesar $3 \mathrm{MPa}$. (Gambar 10)

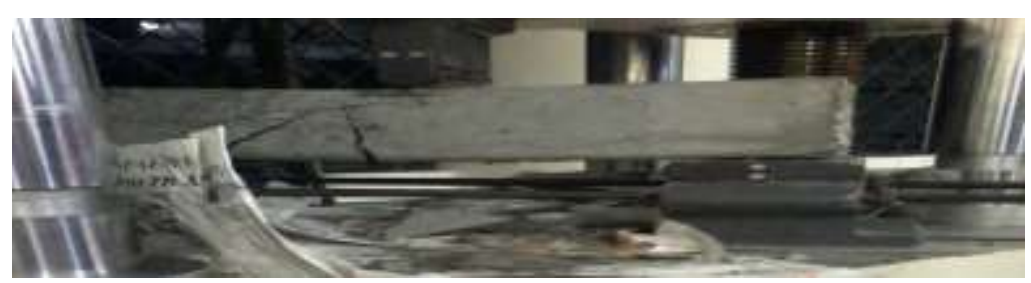

Gambar 9 Pengujian lentur balok beton

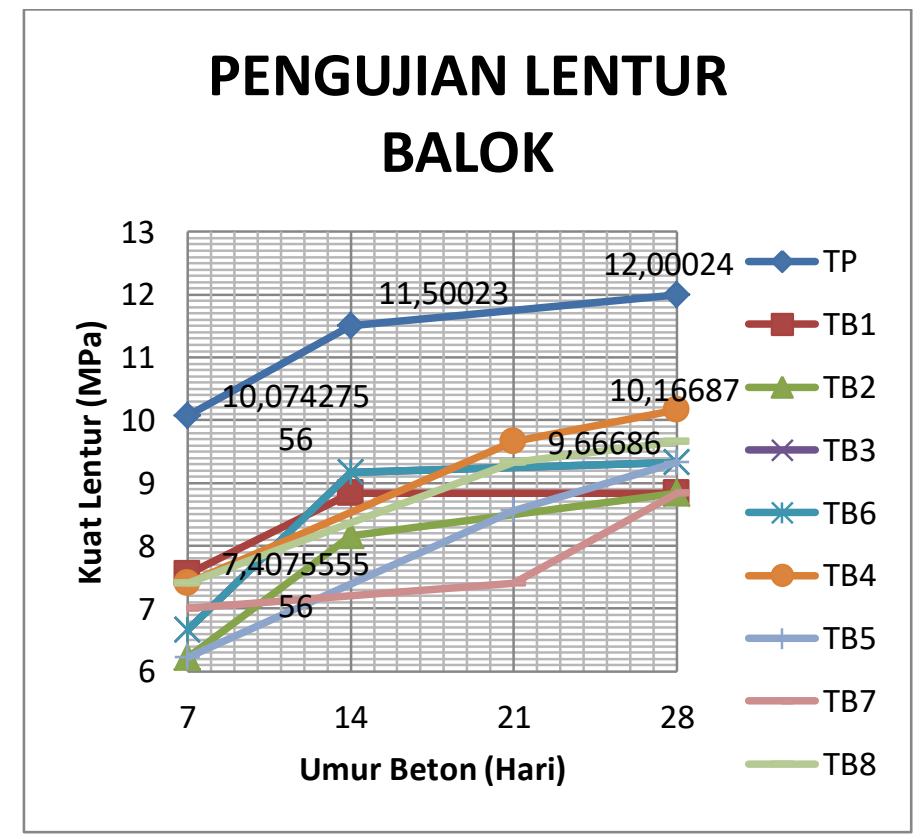

Gambar 10 Perbandingan Hasil Pengujian Lentur Balok 


\section{Balok Tipe TB4}

Hasil pengujian nilai kuat lentur $\left(f_{l t}\right)$ sampel balok beton bertulangan bambu (TB1) pada umur 7, 21 dan 28 hari adalah 7,408 $\mathrm{MPa}$, 9,667 MPa dan 10,167 MPa. Dari hasil pengujian lentur sampel balok tipe TB4 nilai kuat lentur balok semakin meningkat seiring dengan pertambahan umur sampel. Akan tetapi bila dibandingkan dengan nilai dari sampel tipe TP hasilnya masih jauh lebih kecil. Besar selisih pada umur sampel balok pada umur 28 hari adalah sebesar 1,833 MPa. Nilai kuat lentur sampel balok tipe TB4 jika dibandingkan dengan sampel balok bertulangan bambu tipe lainnya mempunyai nilai kuat lentur paling besar. (Gambar 10)

\section{Balok Tipe TB5}

Hasil pengujian nilai kuat lentur $\left(f_{l t}\right)$ sampel balok beton bertulangan bambu (TB1) pada umur 7, 21 dan 28 hari adalah 6,222 $\mathrm{MPa}, 8,555 \mathrm{MPa}$ dan 9,333 $\mathrm{MPa}$. Dari hasil pengujian lentur sampel balok tipe TB5 nilai kuat lentur balok semakin meningkat seiring dengan pertambahan umur sampel. Akan tetapi bila dibandingkan dengan nilai dari sampel tipe TP hasilnya masih jauh lebih kecil. Besar selisih pada umur sampel balok pada umur 28 hari adalah sebesar 2,667 MPa. (Gambar 10)

\section{Balok Tipe TB6}

Hasil pengujian nilai kuat lentur $\left(f_{l t}\right)$ sampel balok beton bertulangan bambu (TB1) pada umur 7,14 dan 28 hari adalah 6,667 $\mathrm{MPa}, 9,167 \mathrm{MPa}$ dan 9,333 $\mathrm{MPa}$. Dari hasil pengujian lentur sampel balok tipe TB6 nilai kuat lentur balok semakin meningkat seiring dengan pertambahan umur sampel. Akan tetapi bila dibandingkan dengan nilai dari sampel tipe TP hasilnya masih jauh lebih kecil. Besar selisih pada umur sampel balok pada umur 28 hari adalah sebesar 2,667 MPa. (Gambar 10)

\section{Balok Tipe TB7}

Hasil pengujian nilai kuat lentur $\left(f_{l t}\right)$ sampel balok beton bertulangan bambu (TB1) pada umur 7, 21 dan 28 hari adalah 7,000 $\mathrm{MPa}$, 7,704 MPa dan 8,833 MPa. Dari hasil pengujian lentur sampel balok tipe TB7 nilai kuat lentur balok semakin meningkat seiring dengan pertambahan umur sampel. Akan tetapi bila dibandingkan dengan nilai dari sampel tipe TP hasilnya masih jauh lebih kecil. Besar selisih pada umur sampel balok pada umur 28 hari adalah sebesar 3,167 MPa. (Gambar 10)

\section{Balok Tipe TB8}

Hasil pengujian nilai kuat lentur $\left(f_{l t}\right.$ ) sampel balok beton bertulangan bambu (TB1) pada umur 7 , 21 dan 28 hari adalah 7,407 $\mathrm{MPa}$, 9,333 $\mathrm{MPa}$ dan 9,667 $\mathrm{MPa}$. Dari hasil pengujian lentur sampel balok tipe TB8 nilai kuat lentur balok semakin meningkat seiring dengan pertambahan umur sampel. Akan tetapi bila dibandingkan dengan nilai dari sampel tipe TP hasilnya masih jauh lebih kecil. Besar selisih pada umur sampel balok pada umur 28 hari adalah sebesar 2,333 MPa. (Gambar 10)

\section{KESIMPULAN}

Berdasarkan hasil pengujian kuat lentur sampel balok bertulangan baja dan bambu, dapat disimpulkan bahwa sampel tipe TB4 dengan kombinasi bentuk tulangan bambu berpenampang $1 / 4 \mathrm{O}$ dengan takikan tidak sejajar berjarak $2 \mathrm{~cm}$ menghasilkan kuat lentur paling besar dibandingkan dengan balok beton bertulangan bambu tipe lainnya. Kuat lentur yang dhasilkan sampel balok tipe TB4 pada umur 28 hari sebesar 10,167 $\mathrm{MPa}$, selisih kuat lentur sebesar 1,833 MPa jika dibandingkan dengan nilai kuat lentur balok tipe TP. 


\section{DAFTAR PUSTAKA}

[BSN] Badan standarisasi Nasional.1994. SNI 03-3399-1994. Metode pengujian kuat tarik kayu di laboratorium.

[BSN] Badan standarisasi Nasional.1996. SNI 03-4154-1996 tentang Metode Pengujian Kuat Lentur Beton dengan Balok Uji Sederhana yang dibebani terpusat langsung.

[BSN] Badan Standarisasi Nasional. 2002. SNI 07-2052-2002 tentang Baja Tulangan Beton.

[BSN] Badan standarisasi Nasional.2008. SNI 7394:2008 Tata Cara Perhitungan Harga Satuan Pekerjaan Beton untuk Konstruksi Bangunan Gedung dan Perumahan.

[BSN] Badan standarisasi Nasional.2011. SNI 2493:2011 tentang tata cara pembuatan dan perawatan benda uji beton dilaboratorium.

Anonim. 1971.Peraturan Beton Indonesia. Departemen Pekerjaan Umum

Budi, AS.2010. Tinjauan Jenis Perekat pada Balok Laminasi Bambu Terhadap Keruntuhan Lentur. Prosiding Seminar Nasional "Pengelolaan Infrastruktur Dalam Menyikapi Bencana Alam", ISBN : 979-489-540-6, 1 Mei 2010.

Frick, H .2004. Ilmu Konstruksi Bangunan Bambu, Pengantar Konstruksi Bambu. Kanisius, Yogyakarta.

Handayani TR, Budi AS, Santoso B. 2014. Kapasitas Lentur Kolom Beton Bertulangan Bambu Petung Polos. e-Jurnal Matriks Teknik Sipil. 2 (1):24-31. ISSN 2354-8630

Pathurahman JF, Kusuma DA. 2003.Aplikasi Bambu Pilinan
Sebagai Tulangan Balok Beton. Civil Engineering Dimension, 5(1):39-44, maret 2003. ISSN 14109530 .

Priastiwi YA, Puwanto. 2012. Korelasi Umur Beton Pada Kuat Lentur. Media Teknik Sipil,7(1) :713,Januari 2012. ISSN 1412-0976.

Sunaryo,Setiyabudi A, Safitri E.2014. Kajian Kapasitas Lentur Balok Beton Bertulangan Bambu Petung Takikan V dengan jarak Takikan 4 $\mathrm{cm}$ dan $5 \mathrm{~cm}$. e-Jurnal Matriks Teknik Sipil,September 2014 :438445. 
JSIL ～Reni Nuraeni dkk. : Kajian Kapasitas Lentur Balok beton Bertulangan Bambu Petung 